University of Michigan Law School

University of Michigan Law School Scholarship Repository

\title{
Techniques for Regulating Military Force
}

\author{
Monica Hakimi \\ University of Michigan Law School, mhakimi@umich.edu
}

Available at: https://repository.law.umich.edu/book_chapters/233

Follow this and additional works at: https://repository.law.umich.edu/book_chapters

Part of the Comparative and Foreign Law Commons, Military, War, and Peace Commons, and the Public Law and Legal Theory Commons

\section{Publication Information \& Recommended Citation}

Hakimi, Monica. "Techniques for Regulating Military Force." In The Oxford Handbook of Comparative Foreign Relations Law

This Book Chapter is brought to you for free and open access by the Faculty Scholarship at University of Michigan Law School Scholarship Repository. It has been accepted for inclusion in Book Chapters by an authorized administrator of University of Michigan Law School Scholarship Repository. For more information, please contact mlaw.repository@umich.edu. 


\section{THE OXFORD HANDBOOK OF}

\section{COMPARATIVE}

\section{FOREIGN}

RELATIONS LAW

Edited by

CURTIS A. BRADLEY 


\section{TECHNIQUES FOR REGULATING MILITARY FOR C E}

\section{MONICA HAKIMI}

DeCisions to use military force can be among the most consequential that a government makes. They can also be difficult to regulate. Even a preliminary survey reveals that there is considerable variation, both across countries and over time within particular countries, in how democratic societies regulate the use of force. ${ }^{1}$ In this Chapter, I examine three regulatory techniques that states use: (1) establish substantive standards on when the government may or may not use armed force, (2) allocate among different branches of government the authority to deploy the country's armed forces, and (3) subject such decisions to oversight or review. After presenting this typology, I reflect on its implications for further comparative research on war powers regulation.

Three points at the outset help frame what follows. First, I am an American lawyer with limited exposure to the war powers regulations of other countries, so I draw heavily on the work of the other contributors to this volume. My approach has certain limits, including that the typology that I present does not purport to be exhaustive or representative. Other accounts of how specific countries regulate war powers would deepen our understanding of those countries and could bring to light additional techniques that are used. Yet building on the work of scholars who are themselves immersed in the relevant legal systems has real virtues. It allows me to capture the law

1 Other studies have come to the same conclusion. See, e.g., Sandra Dieterich, Hartwig Hummel, \& Stefan Marschall, Parliamentary War Powers: A Survey of 25 European Parliaments, Occasional Paper No. 21, Geneva Centre for the Democratic Control of Armed Forces, 9 (2010) (finding "a remarkable variance regarding the war powers of national parliaments in Europe"); Wolfgang Wagner, Dirk Peters, \& Cosima Glahn, Parliamentary War Powers Around the World, 1999-2004, Occasional Paper No. 22, Geneva Centre for the Democratic Control of Armed Forces, 11 (2010) ("The powers of parliaments in this issue area vary widely among democracies around the world."). 
not only as it appears on the books but also as it plays out in discrete institutional settings. It thus enriches the analysis.

Second, war powers regulation can have manifold functions and effects. In some contexts, it might constrain governmental actors and curb the use of force. But it need not serve those functions to be legally relevant or effective. For example, it might instead legitimize decisions to use force and thus empower the people who want to make those decisions. It might structure reasoned public debates. It might make apparent the considerations that are or ought to be at stake in the exercise of military power. It might provide the normative material for criticism or sanction. Or it might catalyze subsequent processes for accountability or reform. We should not assume that war powers regulation always does one thing or that any particular regulatory technique consistently does the same thing(s).

Third, this chapter is mostly descriptive and analytic, rather than normative. It is worth underscoring, however, that no single regulatory technique is inherently good or bad in the abstract. Some situations call for quick and decisive, rather than constrained or cautious, action. Some require secrecy, instead of transparency. Some warrant a serious military response, despite the uncertainties or risks of escalation. And in general, reasonable people can-and often do-disagree about whether, when, and subject to what constraints military operations are desirable. Normative assessments of war powers regulation should, in my view, account for that variance. This chapter's typology can enhance such assessments by expanding an appraiser's frame of reference and illuminating the different ways in which a country's legal architecture can shape behavior on war powers.

\section{Substantive Standards}

One technique for regulating war powers is to establish substantive standards on when the government may or may not use military force. This is a commitment device. It helps preserve a country's long-term military policies by limiting the discretion of governmental officials to deploy the armed forces in the heat of a moment. Yet the stickiness of any such commitment is likely to vary, depending on where the standards are established-for example, whether they are constitutionalized or just legislatively enacted-how easy they are to change, and how precisely they are defined.

Japan stands out for its particularly strict substantive standards on the use of force. As Tadashi Mori explains, any use of force by Japan must be consistent with both the international jus ad bellum and additional restrictions under Japanese law. ${ }^{2}$ The precise content of the jus ad bellum is unsettled, but it generally is thought to prohibit crossborder force except: (1) in individual or collective self-defense, (2) pursuant to the

2 Tadashi Mori, Decisions in Japan to Use Military Force or to Participate in Multinational Peacekeeping Operations, ch. 46 in this volume. 
authorization of the UN Security Council, or (3) with the territorial state's consent. ${ }^{3}$ Beyond that, Japan's Constitution provides that "the Japanese people forever renounce war as a sovereign right of the nation" and that "land, sea, and air forces, as well as other war potential, will never be maintained."4 Historically, this language was thought to permit Japan to use force only in individual self-defense. Further, the Japanese government interpreted that authority narrowly-to mean that it could deploy the armed forces only if an armed attack on Japanese soil occurred, Japan's survival and the protection of its people were at stake, there was not a feasible alternative for repelling the attack, the minimum amount of force that was necessary for self-defense was used, and the force was otherwise consistent with the jus ad bellum's requirements for selfdefense. 5

Over time, the government has interpreted the Constitution more permissively but still to allow the government to use force only in very limited circumstances. As Mori explains, the government now claims the authority to use force in collective selfdefense, so long as such force is consistent with international law, the minimum necessary to repel an attack against a foreign country that is in a close relationship with Japan, and necessary to ensure Japan's survival and the protection of its people. ${ }^{6}$ In addition, the Diet has occasionally enacted legislation to permit Japanese forces to operate outside theaters of hostility or to provide logistical or ancillary support for security operations. ${ }^{7}$ For example, Japanese forces may now support operations in situations that the UN Security Council or General Assembly has determined are threats to international peace and security. ${ }^{8}$ Japanese forces may also participate in international peacekeeping and humanitarian relief operations, subject to certain

${ }^{3}$ UN Charter, arts. 2(4), 39, and 51; see also Military and Paramilitary Activities in and Against Nicaragua (Nicar. v. U.S.), Judgment, 1986 I.C.J. Rep. 14, para. 246 (June 27) (recognizing that an outside state's intervention "is already allowable at the request of the government of a State"). I have recently argued that this formulation of the jus ad bellum is not altogether accurate. See Monica Hakimi, The Jus ad Bellum's Regulatory Form, 112 AM. I. INT'L L. 151 (2018).

4 NrhonKokU KENPŌ [KENPō] [ConsTITUTION], art. 9 (Japan). Japan has considered revising this constitutional provision. As of March 15, 2018, there were seven competing draft amendments in circulation. See Reiji Yoshida, LDP Panel Fails to Form Consensus over Revision of War-Renouncing art. 9, JAPAN TIMEs (Mar. 15, 2018), available at https://www.japantimes.co.jp/news/2018/o3/15/ national/politics-diplomacy/ldp-panel-fails-form-consensus-revision-war-renouncing-article- $9 / \#$.

WrAJgolpBTZ.

${ }^{5}$ Mori, supra note $2 . \quad{ }^{6}$ Id.

${ }^{7}$ E.g., Heisei Jusan-nen Ku-gatsu Juichi-nichi no Amerika Gasshukoku ni oite Hassei shita Terorisuto niyoru Kogeki to ni Taio shite Okonawareru Kokusairengokensho no Mokuteki-tassei no tameno Shogaikoku no Katsudo ni taishite Waga Kuni ga Jisshi suru Sochi oyobi Kanren suru Kokusairengo Ketsugi to ni Motozuku Jindoteki-sochi ni kansuru Tokubetsu-sochi Ho [Anti-Terrorism Special Measures Law], Law No. 113, 2001, amended by Law No. 147, 2003, tentative English summary available at http:// japan.kantei.go.jp/policy/2001/anti-terrorism/102gterohougaiyou_e.html; Iraku ni okeru JindofukkoShienkatsudo oyobi Anzenkakuho-Shienkatsudo no Jisshi ni kansuru Tokubetsu-sochi Ho [Law Concerning the Special Measures on Humanitarian and Reconstruction Assistance in Iraq], Law No. 137, 2003, translated in Mika Hayashi, The Japanese Law Concerning the Special Measures on Humanitarian and Reconstruction Assistance in Iraq, 13 PAC. RiM L. \& PoL'Y J. 579, 587 (2004).

${ }^{8}$ Mori, supra note 2. 
constraints that significantly reduce the risk that they will find themselves in situations where they will need to resort to the use of force. ${ }^{9}$ All of these prescriptions limit a sitting leader's discretion over military policy; they are designed to preserve the country's strong constitutional norm against using force.

Germany's legal architecture similarly subjects use of force decisions to both the international jus ad bellum and other constitutional constraints. With respect to the jus ad bellum, Germany's Basic Law provides that " $[t]$ he general rules of international law shall be an integral part of federal law." 10 The Constitutional Court has interpreted that language to mean that Germany must "compl[y] with the prohibition of the use of force under customary international law." The Basic Law also declares that "[a]cts tending to and undertaken with intent to disturb the peaceful relations between nations, especially to prepare for a war of aggression, shall be unconstitutional . . . [and] made a criminal offence."12

On top of those prescriptions, the Basic Iaw limits the use of military force to circumstances that involve self-defense or are otherwise "expressly permitted by this Basic Law." 13 The Basic Law then recognizes that Germany may "enter into a system of mutual collective security" "[w]ith a view to maintaining peace." 14 Anne Peters explains that, in the past, some within Germany interpreted those provisions to permit deployments only in individual self-defense. ${ }^{15}$ However, the German Constitutional Court adopted a different interpretation in 1994. It clarified that the collective security provision allows German armed forces to be deployed for peacekeeping and other operations that "occur within and pursuant to the rules" of an international organization, such as the United Nations or the North Atlantic Treaty Organization (NATO). ${ }^{16}$ The outer bounds of this collective security authority remain unclear, but German forces may now participate in at least some operations that are not taken to defend the German state.

France has also established substantive standards on the use of military force, but these standards are very different from the ones in Japan and Germany. In France, the standards are crafted not as concrete directives but as broad policy principles, and they are not formally binding. They posit, for example, that the use of force should

9 Id. (describing the 2015 International Peace Support Bill); see also Kokusairengo Heiwaiji-Katsudo to ni taisuru Kyoryoku ni kansuru Horitsu [Act on Cooperation for United Nations Peacekeeping Operations and Other Operations], Law No. 79, 1992, amended by Law No. 157, 2001 and Law No. 118, 2006, translation at http://www.pko.go.jp/pko_j/data/law/pdf/law_e.pdf.

${ }^{10}$ Grundgesetz für die BundesRepublik Deutschland [GG] [Basic LaW] [Constitution], art. 25, translation at http://www.gesetze-im-internet.de/englisch_gg/index.html.

${ }_{11}$ BVerfG, 2 BvE 2/07, July 3, 2007, para. 73, translation at https://www.bundesverfassungsgericht. de/SharedDocs/Entscheidungen/EN/2007/07/es20070703_2bveo00207en.html.

${ }^{12}$ German Basic Law, supra note 10, art. 26(1). ${ }_{13}^{13}$ Id. art. 87(a)(2). $\quad{ }^{14}$ Id. art. 24(2).

${ }_{15}$ Anne Peters, Military Operations Abroad under the German Basic Law, ch. 44 in this volume.

${ }^{16}$ BVerfG, 2 be $1 / 03$, May 7, 2008, para. 62 (citing BVerfG 90, 2 BvE 3/92, July 12, 1994, para. 255), translation available at https://www.bundesverfassungsgericht.de/SharedDocs/Entscheidungen/EN/ 2008/05/es20080507_2bveooo103en.html. The 2008 judgment, which I quote in the main text, has been translated and uses the same language as the 1994 judgment. See Peters, supra note 15, at p.793. 
generally be in response to a serious security threat; based on an assessment of the available alternatives and of the mission's goals, scope, and costs; subject to French political control; and consistent with international law. ${ }^{17}$ These standards are not designed to constrain the government's authority or discretion to act. Instead, they articulate some of the policy considerations that should inform its decisions on whether to use military force.

Countries that incorporate the international jus ad bellum into their domestic legal systems might at some point have to address the question of how changes at the international level affect their domestic authorities. For example, international lawyers increasingly recognize that, over the past fifteen years, the right of self-defense has become more permissive. Although the contours of this right remain unclear and contested, a number of states now claim the authority to conduct operations that reflect very expansive interpretations-particularly, for operations against nonstate actors or in anticipation of attacks that are not temporally immediate. These states also routinely act on their expansive claims, with little or no repercussion. ${ }^{18}$

That dynamic within international law raises important questions for countries that define their domestic authorities by reference to it. For instance, does a change in the jus ad bellum automatically become part of domestic law and license a government to use force in ways that had previously been assumed to be prohibited? Or does the change lack domestic legal effect until it is in some way incorporated through a national process? Insofar as the jus ad bellum for a particular operation is unclear, who within a government may define its content for purposes of domestic law? And what steps, if any, should a country take to ensure that a government does not exploit the fluidity in the jus ad bellum and push it in a permissive direction in order to justify more easily operations under domestic law?

\section{Allocation of Decisionmaking AUTHORITY}

To the extent that force is not proscribed, a country must identify the governmental organ that may decide to use it. Many countries divide decisionmaking authority in this area between the executive and legislative branches of government. Because the executive ultimately implements the decision, the key questions are whether, and if so, when, how, and at what point in the process the legislature must participate.

\footnotetext{
17 For the complete list of these standards, see Mathias Forteau, Using Military Force and Engaging in Collective Security: The Case of France, ch. 45 in this volume.

${ }^{18}$ For a fuller discussion of this trend within the jus ad bellum, see Monica Hakimi \& Jacob Katz Cogan, The Two Codes on the Use of Force, 27 EUR. J. INT'L L. 257, 278-286 (2016).
} 
Some studies suggest that the robustness of any requirement of legislative participation turns on whether the legislature must authorize or consent to an operation before it occurs. ${ }^{19}$ That metric for assessment is too simplistic. If a campaign is sprawling or long-lasting, and the legislature participates only in the initial decision to use force, then its endorsement could become quite attenuated from the actual exercise of military force.

The U.S. experience with the 2001 Authorization for the Use of Military Force (AUMF) is a stark example. There, Congress authorized the president "to use all necessary and appropriate force against those nations, organizations, or persons he determines planned, authorized, committed, or aided the terrorist attacks that occurred on September 11, 2001, or harbored such organizations or persons." ${ }^{20}$ All three branches of the U.S. government have said that the 2001 AUMF authorizes force not only against groups that, in some way, participated in the $9 / 11$ attacks but also against the "associated forces" of those groups. ${ }^{21}$ Further, the executive branch has interpreted the "associated forces" language broadly. For example, the Obama administration claimed that the 2001 AUMF authorized a massive military campaign against the so-called Islamic State in Iraq and Syria (ISIS). The administration's theory was that ISIS was an associated force of al Qaeda because, although the two groups were no longer formally affiliated, they once were, and the links between them had not dissolved. ${ }^{22}$ In addition, the Trump administration has claimed that the 2001 AUMF authorized it to use force against states, like Syria and Iran, that put at serious risk the nonstate groups that collaborate with the United States to defeat ISIS. ${ }^{23}$ Whatever one thinks of these particular applications of the AUMF, Congress's 2001 authorization is not good evidence of its robust participation in U.S. military decisions that were made more than fifteen years later.

Requiring the executive to obtain the legislature's approval for specific military operations can contribute to the interests of transparency and accountability. Open debate within the legislature helps air the reasons for and against an operation. It presses those who want to conduct the operation to defend it publicly. A requirement of legislative approval might also shape the content of the decision. Because a broader range of officials have to accept that using force in a given case is appropriate, legislative

19 See, e.g., Yasuo Hasebe, War Powers, in The Oxford Handbook of Comparative Constitutional Law 463, 464-465 (Michel Rosenfeld \& András Sajó eds., 2012); Wolfgang Wagner, Parliamentary Control of Military Missions: Accounting for Pluralism, Occasional Paper No. 12, Geneva Centre for the Democratic Control of Armed Forces, 4 (Aug. 2006) (describing as countries with "a high level of parliamentary control" those in which "parliament must give its prior approval").

20 Pub. L. No. 107-140, $\$ 2$ (a), 115 Stat, 224 (2001).

21 See U.S. White House, Report on the Legal and Policy Frameworks Guiding the United States' Use of Military Force and Related National Security Operations 4 (Dec. 2016) [hereinafter WHITE HOUSE 2016 REPORT].

${ }^{22}$ Id. at $4-7$.

${ }^{23}$ Letter from David J. Trachtenberg, Deputy Under Secretary of Defense (Policy), to Senator Tim Kaine (Jan. 29, 2018), available at https://www.documentcloud.org/documents/4383185-Kaine-TrumpISIS-war-power-letters.html. 
involvement often has a cooling effect, making use of force decisions more prudent, cautious, and constrained than they otherwise would be. ${ }^{24}$ Yet the legislature's involvement does not necessarily have that effect. If the legislature defers heavily to an executive's security assessments or policy choices, then its endorsement might instead increase the government's willingness to pursue a risky or uncertain military strategy; it might diffuse responsibility for the decision and thus shield the executive from some of the fallout if the operation goes badly. ${ }^{25}$

Countries clearly weigh those eventualities differently. For countries that rely heavily on the military as an instrument of foreign policy, there are real downsides to creating impediments to military action. A recent debate in the United Kingdom is illustrative. U.K. decisions to use force are part of the royal prerogative and fall exclusively within the executive's domain, but the government recently considered changing that arrangement and requiring Parliament to participate in at least some use of force decisions. A 2013 report by the House of Lords Constitution Committee recommended against the change, in part because it could unduly constrain military action. ${ }^{26}$ The committee worried that, if Parliament participated in use of force decisions, it might try to restrict how force is used, which "could harm military effectiveness and limit commanders' freedom of maneuver." 27 Further, a requirement of parliamentary participation might undercut the government's capacity to project its military might. The committee's explained:

There may be instances where the UK's international obligations require the Government to commit to action-for example to achieve collective security with fellow NATO members. In such instances it would be detrimental to the Government's position to be in doubt as to whether they can secure the commitment of Her Majesty's armed forces. ${ }^{28}$

Here, a state's longstanding military policy depends in part on empowering the executive to resort, relatively easily, to the use of force.

\section{Allocation Based on the Nature of the Operation}

States have various options for dividing authority between the executive and legislative branches of government. One approach is to allocate such authority differently,

24 E.g., Dieterich, Hummel, \& Marschall, supra note 1, at 9 ("[European] states with very strong or strong parliamentary war powers tended to be significantly less involved in the 2003 Iraq war compared to states with weak parliaments.").

25 See Jide Nzelibe, Are Congressionally Authorized Wars Perverse?, 59 Stan. L. Rev. 907 (2007).

26 Constitution Committee, Constitutional ARRangements for the Use of Armed Force, 2013-14, HL 46, para. 61 (U.K.), available at https://www.publications.parliament.uk/pa/ld201314/ ldselect/ldconst/46/46.pdf.

${ }^{27}$ Id. at para. $57 . \quad 28$ Id. at para. 58. 
depending on the nature of the operation. Most, if not all, states allow the executive branch to act unilaterally in at least certain kinds of cases-for example, during emergencies or in self-defense. These states might then distinguish those cases from others that require legislative participation.

Consider again Japan. Under the 2015 International Peace Support Act, the Japanese Prime Minister must seek prior Diet approval before deploying the country's armed forces outside Japan. ${ }^{29}$ But as Tadashi Mori explains, prior approval is not requiredand the prime minister may decide unilaterally to use force-if it is necessary to address a domestic emergency. In that event, the prime minister must expeditiously obtain the Diet's retroactive approval or cease the military operation. ${ }^{30}$ This arrangement affords the prime minister limited room to make a unilateral decision only because and to the extent that the nature of the operation requires it.

The situation in Germany is similar. Under both constitutional and statutory law, the Bundestag must generally agree to the "deployment of German armed forces," meaning situations in which German soldiers are involved or are expected to be involved in armed undertakings. ${ }^{31}$ However, German law recognizes an exception and entitles the executive branch to act unilaterally in cases of imminent danger. If the executive acts on its own, it must promptly end the operation or seek the Bundestag's approval. ${ }^{32}$ Separately, German law clarifies that the Bundestag need not authorize military operations that do not have the characteristics of a "deployment"-operations in which the military takes measures that are only preparatory, for planning purposes, or to provide humanitarian aid, without any concrete expectation of combat. ${ }^{33}$ Again, the nature of the operation is what determines whether and when the Bundestag must participate.

The U.S. president has discretion to act unilaterally in a much broader range of cases, but that range is still defined partly by the nature of the operation. As Curtis Bradley explains, the bounds of executive authority in this area are unclear and contested. Most believe that, as a matter of original understanding, the Constitution entitles the president to decide unilaterally to use force only in cases of self-defense. ${ }^{34}$ But that understanding has eroded over time, as the executive has claimed the authority to

29 Kokusai Heiwa Kyōdōtaisho jittai ni saishite Waga Kuni ga jisshisuru Shogaikoku no Guntai nadoni taisuru Kyōryoku Shijikatsudō nado ni kansuru Hōritsu [Law Related to the Implementation of Japan's Cooperative Support for the Armed Forces of Foreign Countries in Circumstances of International Peace and Security Cooperation Activity] [International Peace Support Act], Law No. 77, 2015, arts. 4-6, available at http://www.cas.go.jp/jp/gaiyou/jimu/housei_seibihtml, English language summary available in JAPAN Ministry of Defense, 2015 Defense of Japan Annual White Paper 147 fig. II-1-3-12, available at http://www.mod.go.jp/e/publ/w_paper/2015.html.

30 Mori, supra note 2.

31 Federal Law on Parliamentary Approval of International Deployment of Armed Forces [2005 Parliamentary Act], Mar. 18, 2005, BGBl. 2005 I, 775, \$ 1(2), unofficially translated in Katja S. Ziegler, The Model of a "Parliamentary Army" Under the German Constitution, House of LoRds ConsT. COMM. (Dec. 7, 2005), at Annex II, available at https://publications.parliament.uk/pa/ld200506/ldselect/ldconst/ 236/5120707.htm \#n141.

${ }^{32} I d$ at $\$ 5 . \quad{ }^{33} I d$. at $\$ 2(2)$.

${ }^{34}$ Curtis A. Bradley, U.S. War Powers and the Potential Benefits of Comparativism, ch. 42 in this volume. 
use force without congressional participation in an increasingly expansive set of circumstances. Thus, when the executive articulated its legal justification for the 2011 Libya operation, it recognized only "one possible constitutionally-based limit on this presidential authority to employ military force in defense of important national interests." ${ }^{35}$ It asserted that "a planned military engagement that constitutes a 'war' ... may require prior congressional authorization." ${ }^{36}$ It then defined "war" in terms of the "'anticipated nature, scope, and duration' of the use of force," and contended that "this standard generally will be satisfied only by prolonged and substantial military engagements. ${ }^{37}$ In short, the president now claims unilateral authority for all but the most extensive military operations, at least insofar as Congress has not expressed a contrary view. ${ }^{38}$ The claim rests partly on the nature of the operation.

\section{Allocation Based on the Duration of the Operation}

Another approach for allocating decisionmaking authority is temporal-to permit the executive branch to use force only for a set period absent legislative approval. The Japanese and German examples show that this approach can be used concurrently with the first. In each of those countries, the executive may act unilaterally in certain kinds of cases for very limited periods. It must expeditiously obtain the legislature's consent in order to continue those operations. In other countries, the executive's unilateral authority is defined primarily in temporal terms. It has broad discretion to decide on its own to use military force, but it may do so only for a set period.

The temporal approach reflects a balance. The executive has discretion to conduct operations that it decides, based on its expertise, are in the national interest. But its discretion is limited to inhibit it from taxing the country for prolonged periods without buy-in from other domestic actors. This approach carries some risks. First, the costs of extricating the armed forces from a theater of combat might be very high or unpredictable. An executive that unilaterally takes the country into hostilities might box the legislature in, such that it feels compelled to acquiesce in an operation that it thinks is bad policy and would not have accepted ex ante. Second, if a country's enemies are wellattuned to its domestic situation, they might try to wait out the clock in the expectation or hope that the country will unilaterally withdraw its forces at a date certain.

The relevant time period varies by country. In the Czech Republic, parliamentary approval is required after sixty days. ${ }^{39}$ In France, the period is four months. ${ }^{40}$ In the

${ }^{35}$ Memorandum Opinion from Caroline D. Krass, Principal Deputy Assistant Attorney General, Office of Legal Counsel, to the Attorney General, "Authority to Use Military Force in Libya" (Apr. 11, 2011).

${ }^{36}$ Id. $\quad{ }^{37}$ Id. $\quad{ }^{38}$ See also Bradley, supra note 34 (analyzing U.S. executive claims).

39 Ústava České Republiky [Constitution], 1/1993 Sb. (as amended), art. 43, translated at http://www.psp.cz/en/docs/laws/constitution.html.

401958 CoNst. art. 35, translated at http://www.conseil-constitutionnel.fr/conseil-constitutionnel/ english/constitution/constitution-of-4-october-1958.25742.html. 
United States, the situation is more complicated. As discussed, the U.S. president claims the authority to act unilaterally for the vast majority of operations. However, the War Powers Resolution (WPR) requires him to withdraw U.S. forces within sixty days from situations in which hostilities are occurring or are expected to occur unless: (1) Congress authorizes the operation or extends the sixty-day clock, (2) Congress is physically unable to meet due to an attack on the United States, or (3) the president decides that "unavoidable military necessity respecting the safety of the United States Armed Forces requires the continued use of such armed forces" for up to thirty additional days. ${ }^{41}$ Congress may also cut short the sixty-day period, at least for operations involving hostilities outside the United States. ${ }^{42}$

The Obama administration softened the bite of the WPR clock in 2011, when it narrowly interpreted the circumstances that qualify as "hostilities." The administration asserted that its participation in a multilateral operation in Libya did not need to be approved or terminated within sixty days because the nature of the U.S. mission, the exposure of U.S. armed forces, the risk of escalation, and the military means employed by the United States were all sufficiently limited so as not to count as hostilities under the $\mathrm{WPR}^{43}$ The practical effect of this position is to narrow the range of cases that are subject to the sixty-day clock.

\section{Allocation of Ancillary Authorities}

Finally, a legislature might have ancillary authorities with which to influence use of force decisions. For example, although the Japanese Constitution does not assign to any branch of government the authority to decide to use military force, the Diet has repeatedly passed legislation to elaborate on the sparse constitutional text. Here, a legislature uses its interpretive and prescriptive authorities to define the circumstances in which the armed forces may be deployed and thus to delineate the scope of the executive's authority in this area.

In the United States, Congress controls the purse, and the Constitution provides that no appropriation " $[\mathrm{t}] \mathrm{o}$ raise and support Armies... shall be for a longer Term than two Years." ${ }^{\prime 4}$ Many consider this to be Congress's principal mechanism for participating in use of force decisions. ${ }^{45}$ It requires Congress periodically to decide what military

41 War Powers Resolution $\$ 4$ (a)(1) \& 5, Pub. L. No. 93-148, 87 Stat. 555 (1973), 50 U.S.C. $\$$ 1543-1544 [hereinafter WPR].

${ }^{42}$ Id.

${ }^{43}$ Libya and War Powers: Hearing Before the S. Foreign Relations Comm., 112th Cong. 7-40 (June 28, 2011) (testimony of Harold Hongju Koh, Legal Adviser, U.S. Department of State), available at http://fas.org/irp/congress/2011_hr/libya.pdf.

${ }^{44}$ U.S. ConsT., art. 1, sec. 8, cl. 12.

${ }^{45}$ See, e.g., Reid Skibell, Separation-of-Powers and the Commander in Chief: Congress's Authority to Override Presidential Decisions in Crisis Situations, 13 Geo. Mason L. Rev. 183, 195 (2004) ("[T]he spending power has become Congress's primary tool in influencing military and, to a large degree, 
capabilities the president will have and thus whether he will be equipped to implement his preferred military policies. It might also exert some control on his decisions. Congress has occasionally used its spending power to limit specific military operations. Moreover, even when it does not try to restrict the president's decisions, his dependence on it for funding gives him an incentive to obtain its support, both before initiating a major military operation and over the course of the campaign. Yet in the modern era, various factors-ranging from a lack of political will in Congress to the complexities of the appropriations process to the vast scale of the U.S. military-limit the extent to which the Congress uses its appropriations power to participate in specific use of force decisions. ${ }^{46}$

\section{Oversight AND REVIEW}

No matter whether the decision to use force is made unilaterally or with legislative participation, it might be subject to various mechanisms for oversight or review. These mechanisms again differ in their details, but most involve the sharing of information. They help bring to light the facts that triggered the use of force, whether alternatives to military force were considered or taken, the operation's objectives, its expected duration, or its likelihood of success. Such information can then be used to hold the government accountable for a decision. It might also shape the content of a decision. Officials might be disinclined to exceed their authorities or to act imprudently if they know that bad decisions will be publicly scrutinized or sanctioned.

\section{Legislative Oversight}

Legislatures have different tools for reviewing use of force decisions. They might summon executive branch officials for public hearings. They might interrogate these officials orally or in writing. They might demand access to certain documents. Or they might initiate processes of judicial review. ${ }^{47}$

A legislature's oversight authority can but need not be coextensive with its authority to participate in the decision to use force. The distinction was evident, for example, in

foreign policy decisions."); John Yoo, The Continuation of Politics by Other Means: The Original Understanding of War Powers, 84 CAL. L. REv. 167, 295, 297 (1996) (arguing that "the Framers intended to participate in war-making by controlling appropriations" and that this framework perseveres in the modern era because "Congress fully understands that its appropriations may be used to check executive military decisions").

46 See generally Bruce Ackerman \& Oona Hathaway, Limited War and the Constitution: Iraq and the Crisis of Presidential Legality, 109 MiCH. L. ReV. 447 (2011).

47 See Dieterich, Hummel, \& Marschall, supra note 1, at 11. 
the 2015 German Constitutional Court judgment on a rescue operation in Libya. ${ }^{48}$ The operation took place in 2011, after the Libyan civil war broke out but before the UN Security Council authorized the use of force. At the German chancellor's direction, German forces evacuated 132 people from an industrial base in Libya, without any combat action. Afterward, a parliamentary group filed a complaint before the Constitutional Court, arguing that the executive's unilateral decision to use force had to be submitted to the Bundestag for its retroactive approval. The court disagreed. It determined that the executive had unilateral authority to act because the situation presented an emergency. However, the court then said that the executive was obligated to inform the Bundestag of the details of the operation, so that it could meaningfully perform its oversight functions. Here, the executive was not required to obtain the Bundestag's authorization for the use of force but was required to share with it information so that it could review the decision.

Other countries also require the executive branch to inform the legislature of decisions to use force. In France, the executive must, within three days of initiating a sustained operation in another country, inform Parliament of the operation and describe its objectives. ${ }^{49}$ The French Parliament may then choose to debate, without taking a formal vote on, the decision. In the United States, the WPR requires the president to inform Congress within two days of a deployment. ${ }^{50}$ U.S. presidents have routinely complied with this reporting obligation, even though they have resisted other aspects of the WPR.

The role of the U.K. Parliament in overseeing use of force decisions is more informal and, as Katja Ziegler explains, in flux. ${ }^{51}$ The House of Lords does not have any legal authority to participate in use of force decisions, but the government has in recent years recognized a constitutional convention-an accepted practice-of consulting with Parliament and affording it the opportunity to debate and vote on decisions to use force before troops are committed. ${ }^{52}$ This convention, which was initiated with the 2003 Iraq War, appears to have had some bite in a few cases. Perhaps most notably, the prime minister chose in 2013 to abide by Parliament's vote not to intervene in

${ }_{48}$ BVerfG, 2 BvE 6/11, Sept. 23, 2015, available at http://www.bverfg.de/e/es20150923_2bveooo61 1en. html. For an excellent review of this decision, see Anne Peters, The (Non-)Judicialisation of War: German Constitutional Court Judgment on Rescue Operation Pegasus in Libya of 23 September 2015 (Part I), EJIL TALK! (Oct. 21, 2015), http://www.ejiltalk.org/the-non-judicialisation-of-war-german-constitutional-courtjudgment-on-rescue-operation-pegasus-in-libya-of-23-september-2015-part-1/.

491958 Const. art. 35; see also Forteau, supra note 17 (explaining that the executive need not inform Parliament of military operations, like those to rescue nationals abroad, that do not fall within the scope of art. 35 because they are so small in scale that they do not qualify as "interventions").

50 WPR, supra note $41, \$ 4$.

${ }^{51}$ Katja S. Ziegler, The Use of Force by the United Kingdom: The Evolution of Accountability, ch. 43 in this volume.

52 For an argument that a constitutional convention on parliamentary oversight has also emerged in Canada, see Ryan Patrick Alford, War with ISIL: Should Parliament Decide?, 20 Rev. Const. STuD. 118 (2015). Alford argues that the Canadian convention requires a parliamentary debate before troops are deployed in combat operations. 
Syria in response to that government's use of chemical weapons. ${ }^{53}$ But in practice, the convention has not consistently been followed, and its scope of application remains unclear. ${ }^{54}$ Indeed, when Syria was caught still using chemical weapons in 2018, the prime minister participated in military strikes without first taking the issue to Parliament. ${ }^{55}$

As discussed, the U.K. government has considered transforming this convention into a formal requirement of parliamentary participation. However, a 2013 report by the U.K. House of Lords Constitution Committee ultimately argued for preserving it in its current form, as a tool for political oversight and control. ${ }^{56}$ The committee argued that one benefit of this arrangement is that formalization might invite courts to review more rigorously the government's use of force decisions. ${ }^{57}$ "There was consensus amongst our witnesses that the appropriate forum for controlling and scrutinising deployment decisions is Parliament, not the courts." ${ }^{58}$

\section{Judicial Oversight}

The United Kingdom is not alone in limiting the availability of judicial review in this area. As Mathias Forteau explains, French courts regularly invoke the so-called "act of government theory" to find that they lack jurisdiction to rule on claims against the government concerning the use of force. ${ }^{59}$ Similarly, Curtis Bradley explains that U.S. "courts in the modern era have invoked various 'justiciability' limitations to avoid addressing these issues." ${ }^{\text {" I }}$ In these countries, courts restrain themselves and decline to review specific use of force decisions. By contrast, German courts have actively overseen such decisions. ${ }^{61}$ They have repeatedly assessed the legality of particular military operations.

Courts might be institutionally ill-equipped to oversee use of force decisions for any number of reasons. They might lack the expertise necessary to assess a government's national security claims. They might be incapable of checking the government's factual assertions. They might have to rely on secret information that they cannot then use to

53 Prime Minister David Cameron, Statement to House of Commons, Sept. 9, 2013, available at https://publications.parliament.uk/pa/cm201314/cmhansrd $/ \mathrm{cm} 130909 / \mathrm{debtext} / 130909$-0001.htm ("I am clear that it was right to advocate a strong response to the indiscriminate gassing of men, women and children in Syria, and to make that case in this Chamber. At the same time I understand and respect what this House has said. So Britain will not be part of any military action....").

${ }^{44}$ See Claire Mills, Parliamentary Approval for Military Action, Briefing Paper No. 7166, at 3, House OF COMMONS LIBRARY (May 12, 2015), available at https://researchbriefings.parliament.uk/ ResearchBriefing/Summary/CBP-7166.

${ }^{55}$ See House of Commons Library, Parliamentary Approval for Military Action (Apr. 17, 2018), available at https://researchbriefings.parliament.uk/ResearchBriefing/Summary/CBP-7166\#fullreport.

56 CONSTitutional ARRANGEMENTS fOR THE USE OP ARMED FORCE, supra note 25, paras. 61 and 64

${ }^{57}$ Id. at para. 54. $\quad{ }^{58}$ Id. $\quad{ }^{59}$ Forteau, supra note 17.

${ }^{60}$ Bradley, supra note 34 , at p.760. ${ }^{61}$ Peters, supra note 15. 
justify their decisions. ${ }^{62}$ And if the country's laws do not define, in relatively specific terms, when force is or is not permissible, they might lack judicially manageable standards based on which to evaluate specific operations. It is not surprising that U.K., French, and U.S. courts refrain from assessing use of force decisions, given that the executive in each country has or claims to have so much discretion in this area; these courts lack concrete legal standards to apply. Inviting courts to review the legality of specific operations thus can put them in difficult positions. It might require them to make the kinds of judgments that are better suited for the other branches of government.

But judicial review can also be quite valuable. First, the possibility of courts evaluating specific decisions might check the officials who want to make those decisions and inhibit them from overstepping their legal authorities. In this way, judicial review can help preserve the basic structure of and allocation of authority within a government. Second, when courts apply the law in concrete cases, they elaborate on its content and flesh out the legal framework that governs future decisions. This lawmaking component of judicial decisions is especially useful if the constitutional and statutory texts that regulate the use of force are sparse, inconsistent, or disconnected from contemporary sensibilities or realities. For example, the 1994 decision of the German Constitutional Court on collective security operations in effect updated Germany's Basic Law for the modern era. Third, judicial review of governmental decisions prods those who exercise authority to justify their decisions publicly, in legal terms, and for external scrutiny. It thus contributes to basic rule of law values. ${ }^{63}$

\section{Diffuse Oversight}

Most democratic states also have other, more diffuse mechanisms for oversight or review. In the case of the United States, Jack Goldsmith has described a national security apparatus that is heavily scrutinized by an amalgam of actors, who are formally disconnected from one another and operate from both within and outside of government. ${ }^{64}$ As Goldsmith describes it, dozens of executive branch officials, with diverse institutional perspectives and priorities, weigh in on national security decisions, especially as they relate to targeted killing and covert operations. These officials can shape the president's decisions before they are taken and through systematic assessments

${ }^{62} C f$. Mohamed v. Jeppesen Dataplan, Inc., 614 F.3d 1070 (9th Cir. 2010) (en banc).

${ }^{63}$ Here, I am relying on a conception of the rule of law that Jeremy Waldron has been especially influential in advancing. In this conception, the rule of law is not just about constraining the exercise of authority with relatively precise, transparent, and impartially administered standards. It is also about committing to "a certain method of arguing about the exercise of public power" and creating "opportunities for active engagement in the administration of public affairs." Jeremy Waldron, The Rule of Law as a Theater of Debate, in Dworkin AND His CRITICs 319, 330 (Justine Burley ed., 2004); Jeremy Waldron, The Concept and the Rule of Law, 43 GA. L. Rev. 1, 9 (2008).

${ }^{64}$ Jack Goldsmith, Power and Constraint: The Accountable Presidency after 9/11 (2012). 
over time. In addition, executive branch officials routinely leak information about the government's security operations to the press. This allows the operations to be aired publicly and contested by civil society groups that oppose them. If enough constituents disagree with the government's military decisions, they can then try to change its policies by voting for different officials in the next election.

\section{REFLECTIONS ON COMPARATIVE WAR POWERS WORK}

Although the above typology is only preliminary, it raises fairly fundamental questions about comparative war powers work: to what extent and in what ways is such work valuable? How might it help lawyers and policymakers who make or analyze use of force decisions?

There are at least two reasons to be cautious. First, countries vary significantly in how strictly and through what techniques they regulate the use of force. Indeed, the relevance of a given technique might vary even within a single country. Take the division of authority, as between the U.S. president and Congress, on decisions to use force. Although the president's authority in this area has expanded considerably since World War II, there continues to be widespread support for the norm that requires the president to obtain Congress's approval before initiating at least some armed operations. Yet the salience of that norm is extremely variable. It depends on a host of case-specific factors, including the security problem that the president wants to address, the nature of the anticipated operation, and the politics that surround it, both within and outside of the United States. For example, President Obama sought congressional support when he was contemplating even a limited strike against Syria for its use of chemical weapons in $2013,{ }^{65}$ but he did not go to Congress for the fairly extended campaign against Libya in $2011 .{ }^{66}$ Likewise, he invoked Congress's authorization in the 2001 AUMF to justify using defensive force against al-Shabaab militants in Somalia, but he relied on his own constitutional authority for very similar strikes against Houthi militants in Yemen. ${ }^{67}$ The point is not that the norm on congressional authorization does not do any work but that the work that it does is highly contingent on the circumstances of a case.

A similar point might be made about other countries. Since the U.K. convention on parliamentary consultations emerged in 2003 , its salience has varied considerably across cases. The differential treatment of the 2013 and 2018 Syria cases is illustrative.

${ }^{65}$ See Peter Baker \& Jonathan Weisman, Obama Seeks Approval by Congress for Strike in Syria, N.Y. TIMEs (Aug. 31, 2013), available at http://www.nytimes.com/2013/og/01/world/middleeast/syria. html.

${ }_{66}^{66}$ See supra notes $35-37$ and accompanying text.

67 WHITE HOUSE 2016 REPORT, supra note 21 , at 5, 7, 17, 18. 
Likewise, the circumstances in which Germany may participate in multilateral operations under the Basic Law's collective security provision are unsettled and, in at least some respects, contingent on the facts. ${ }^{68}$ Such variance within countries complicates efforts to extract general principles on how they regulate the use of force, let alone general principles that can then be translated for comparison and contrast with the entirely different institutional arrangements of a foreign country.

The second reason why comparative work on war powers is particularly challenging is that, relative to other areas of foreign affairs, this one seems more deeply connected to each country's national ethos-its sense of its own character as a country. Here, Philip Bobbitt's work on what he calls ethical reasoning in U.S. constitutional law is illuminating. As Bobbitt describes it, ethical reasoning invokes a country's ethos, either expressly or by implication, as a justification or source of authority for concrete legal positions. Ethical reasoning is not the same as moral reasoning. It does not "claim that a particular solution is right or wrong in any sense larger than that the solution comports with the sort of people we are and the norms we have chosen to solve political and customary constitutional problems." ${ }^{69}$ To say that ethical reasoning is salient in war powers regulation is to say that the country's ethos is routinely at issue and part of what is at stake in concrete legal battles and decisions on the use of force. ${ }^{70}$ War powers regulation would reflect, be a vehicle for arguing about, and help shape deeply held views about what the country stands for.

Of course, people within a country might disagree about its ethos. For example, most Americans seem to accept that the United States is and ought to be a military superpower. But they routinely disagree about when, where, and how it ought to project its military might. This means that the American ethos relating to the military is not entirely stable or shared. The "true" ethos might be hard to pin down, and arguments about it might not be reliable indicators of what it really is. ${ }^{71}$ Ethical reasoning would still be prevalent in U.S. war powers regulation if Americans routinely tap into variants of the national ethos to argue about or make specific decisions on the use of force.

They seem to do quite a bit of that. As a concrete example, recall that the U.S. executive branch claims that the president has unilateral authority "to direct U.S. military forces in engagements necessary to advance American national interests

${ }^{68}$ See Peters, supra note 15.

${ }^{69}$ Philip Bobbitt, Constitutional Fate 94-95 (1982). In Constitutional Fate, Bobbitt described ethical argument as resting on "a characterization of American institutions and the role within them of the American people." Id. Bobbitt also advanced, as a particular vision of the U.S. constitutional ethos, the commitment to limited government. Id. at 230 . He and others have since recognized that that vision is too narrow and not the only plausible way to characterize the American ethos. See Philip Bobbitt, Reflections Inspired by My Critics, 72 Tex. L. Rev. 1869, 1937 (1994); Richard Primus, Response, The Functions of Ethical Originalism, 88 Tex. L. Rev. SeE Also 79, 80-81 (2010).

${ }^{70}$ See Primus, The Functions of Ethical Originalism, supra note 69, at 82, 89.

71 See Richard Primus, Unbundling Constitutionality, 80 U. CHI. L. REV. 1079, 1133-1135 (2013); Jack M. Balkin, The New Originalism and the Uses of History, 82 FordHAM L. Rev. 641, 678 (2013). 
abroad," except perhaps when those engagements amount to full-scale "wars." ${ }^{72}$ The executive branch has never publicly articulated the criteria for identifying the national interests that this claim covers. But it has invoked the claim to justify, on a case-by-case basis, forcible operations for a range of amorphous foreign policy goals. According to the executive branch, the national interests for which the president may unilaterally decide to use force include things like preserving stability in various parts of the world, bolstering the credibility of NATO or the United Nations, and deterring of the use and proliferation of chemical weapons. ${ }^{73}$

These executive branch justifications for the use of force are dripping with ethical reasoning. They invoke and rely on a particular view of the United States and its relationship with the rest of the world. In this view, virtually any security problem anywhere in the world affects U.S. interests, deploying the U.S. military is often the appropriate response, and the military is such a routine part of U.S. foreign policy that the president need not go through all that much trouble to sell particular operations to the U.S. Congress or, for that matter, to the American public; using the military to address global security issues is just part of what we do and who we are as Americans.

Ethical reasoning also seems to animate how other countries regulate war powers. Remember that one reason that the United Kingdom chose not to turn the convention on parliamentary consultations into a binding requirement is that any such requirement might be "detrimental" to U.K. foreign and military policy. ${ }^{74}$ This reasoning again has ethical notes. It reflects a vision of the United Kingdom's standing in the world, defined partly through the projection of a strong and active military. Along similar lines, when Germany's Constitutional Court applies the Basic Law's collective security provision, its reasoning seems to be heavily ethical. It portrays Germany as a good global citizen that is committed to establishing peace and security by working through international institutions. It defines Germany's ethos in those terms.

If ethical reasoning drives a lot of war powers regulation, as it seems to do, then national officials are likely to be hesitant to use comparative methods to address specific use of force questions. Rather than look to other countries for guidance, these officials will probably tap into their own sense of the national ethos. This might be true even as between countries, like the United States and the United Kingdom, that share certain histories and traditions, and use many of the same regulatory techniques. The ethos is ultimately a national construct. Moreover, where ethical reasoning is prominent, comparative war powers work is unlikely to have much explanatory force. The questions of why specific countries adopt the regulatory techniques that they do or

\footnotetext{
${ }^{72}$ Memorandum Opinion for the Counsel to the President, Office of Legal Counsel, "April 2018 Airstrikes Against Syrian Chemical-Weapons Facilities" (May 31, 2018).

${ }^{73}$ For an excellent overview, see Curtis Bradley \& Jack Goldsmith, OLC's Meaningless "National Interests" Test for the Legality of Presidential Uses of Force, LAWFARE (June 5, 2018), available at https:// www.lawfareblog.com/olcs-meaningless-national-interests-test-legality-presidential-uses-force.

${ }^{74}$ Constitutional Committee, supra note 26, at para. 58.
} 
how those techniques play out in concrete cases will best be answered by looking internally.

Yet this does not mean that comparative research on war powers regulation is fruitless. Quite the contrary. Because ethical reasoning seems so prominent in this area, such research can help crystallize and bring to the public consciousness aspects of a national ethos that otherwise go unnoticed. Learning how different countries regulate the use of force can deepen our understanding not only of those countries but also, and perhaps more critically, of our own. It can bring into sharp relief what a country is really about-how it defines itself as a polity and conceives of its relationship to the rest of the world. 